\title{
Public Relations Consultancy Potential in the Muslim World: Public Relations from Islamic Perspective
}

\author{
Yongbao Wang ${ }^{1}$, Yong $\mathrm{Ma}^{2}$ \\ ${ }^{1}$ School of Oriental Studies, Xi'an International Studies University, Xi'an 710061, Shaanxi, China \\ ${ }^{2}$ Institute of Publishing Science, Chang'an University, Xi'an 710064, Shaanxi, China
}

\begin{abstract}
The concept of Public Relations (PR) is widely applied in a great diversity of institutions or organizations and it is considered as a powerful instrument to gain the mutual understanding and reciprocal benefits from stakeholders. This paper attempts to offer the certainly important principles and objectives of Islamic Public Relations (IPR), as well as to explore its features and characteristics based on the Holy Quran and the Noble Hadith in order for us to further appreciate the potential of IPR consultancy in the Muslim World. Hopefully, the Islamic values which the paper has presented can benefit PR practitioners in their particular field.
\end{abstract}

Keywords: Islamic public relations, Cognition, Brotherhood, Muslim world, Ethics

\section{INTRODUCTION}

Public Relations (PR) is considered as social phenomenon whose rotes derived from time of existence of human beings on the earth. There is no doubt that whenever and wherever, as long as human beings are congregated and assembled together as a community, their relations have automatically emerged and have sustainably grown in order for them to face and fulfill the necessities and needs of their life (Muhi \& Samir, 1985) [1]. With the development of society or community in its diversities, the PR by its new meaning with new forms had been arisen in end of $19^{\text {th }}$ century and has been tremendously developed since the last century in different fields. Due to the complexity of social life and establishment of different institutions for protecting the interest of people, the connections and links with people and their interest have become necessary for those associations, institutions or organizations to setting up programmes and strategies in order to achieve certain objectives through effective approaches (Zain, 2008) [2].

Consultancy as the practice of giving expert advice within a particular field, e.g. risk management consultancy in finance, which is connected with PR plays a very important role in the society and by which the communication services provided almost are connected with all aspects of our daily life in religion, finance, health care, family, etc. As a PR consultant (also known as a publicist or media relations consultant), he/she may encounter many exciting challenges which could be given by clients or employers. Faced with one of the given challenges, we should come up with solutions to inform, influence or persuade people. Those solutions may involve communication techniques such as getting publicity in the media (television, radio, newspapers, Internet, etc.), directly attaching with publics and organizing public events. Apart from this, as PR consultant who always needs to plan a PR project for the predictable results that would require him/her to work with many interesting and important people. Therefore, as IPR consultant, he/she should be qualified not only with skills but also with certain knowledge about Islam (Al-Kandari \& Gaither, 2011) [3], especially the principles and the objectives of IPR and only through which we may see the potential of PRC in the Muslim world.

\subsection{Cognition of Human Dignity Endowed by Allah the Exalted}

\section{The Principles of Islamic Public Relations}

The PR would only be well established in a cultural and civilized environment, within which human beings can recognize and believe in his/her dignity, merit and significance as a human being who is endowed with rights as well as is required to fulfill his/her duties towards others in the society. Such connotation of the PR was provided at outset of first Islamic society established in the Medina under the leadership of the Prophet Muhammad (Peace Be Upon Him) " and had sequentially been practiced by righteous caliphates; Allah the Almighty says in the Holy Quran: "And We have certainly honoured the children of Adam and carried them on the land and sea and provided for them of the good things and preferred them over much of what We have created, with [definite] preference." (Al-Isra: 70)

\footnotetext{
"Whenever and wherever the name of the Prophet Muhammad has appeared throughout this paper, the four alphabets (PBUH) are used to represent the phrase of "Peace Be Upon Him".
} 


\subsection{Reciprocal Respect}

Islam, as the perfected and approved Religion by Allah the Almighty and as the best way of life, has organized and systematized the relations between man to man, society to society and nation to nation, Muslims themselves in particular, and between them and non-Muslims in general. This Religion always calls us to respect each other and emphasizes on eschewing of vilify and taunt, Allah the Almighty says in the Holy Quran: "O you who have believed, let not a people ridicule [another] people; perhaps they may be better than them; nor let women ridicule [other] women; perhaps they may be better than them. And do not insult one another and do not call each other by [offensive] nicknames. Wretched is the name of disobedience after [one's] faith. And whoever does not repent - then it is those who are the wrongdoers." (Al-Hujurat: 11). "And do not insult those they invoke other than Allah, lest they insult Allah in enmity without knowledge. Thus We have made pleasing to every community their deeds. Then to their Lord is their return, and He will inform them about what they used to do." (Al-Anam: 108)

\subsection{Equality of Human Beings}

In order to awaken all humankind to recognize the complete equality among them, Allah the Exalted calls in the Holy Quran: "O mankind, reverence your Guardian-Lord, Who created you from a single person, created of like nature, his mate and from them twain scattered (like seeds) countless men and women. And reverence Allah, through Whom you ask one another, and the wombs. Indeed Allah is ever, over you, an Observer." (An-Nisa: 1).

In this Quranic Verse, Allah the Exalted tells us that all humankind have one origin, having been created from one father, Adam (peace be upon him). Therefore, they should always be conscious of this origin, since they share one genealogy and one ancestor, whether they are Muslims or non-Muslims; and since we are all the creatures of Allah, therefore our mutual rights and duties should be referred to HIM. Again, Allah the Almighty clarifies: "O mankind, indeed We have created you from male and female and made you peoples and tribes that you may know one another. Verily, the most noble of you in the sight of Allah is the most righteous of you. Indeed, Allah is Knowing and Acquainted.” (Al-Hujurat: 13).

This Verse emphasizes that Allah has not only created mankind from one father and one mother, but also made them into peoples, races, tribes and nations that are convenient labels so that they may know one another by the differing characteristics and make the real brotherhood prevail among them; yet cannot bear enmity to fight or dominate each other. In this sense, the Prophet Muhammad (PBUH) said: "People are as equal as the teeth of a comb, nobody is better than another except for whosoever reverence Allah the Exalted." (Ibn Shuja', 1986) [4]. Therefore, from the Islamic point of view, the existing differences among people are not those of one's birth or social status, rich or poor, white or colored, but their excellence in what Islam had advocated that belief in Allah and worship Him alone, fulfill His injunctions and follow his Prophet - Muhammad's way of obeying Allah and reverencing HIM. As Allah had decreed that the criteria of distinction between people are true piety, the Prophet (PBUH) in his Farewell sermon announced this as the criteria of preference and superiority between Arabs and non-Arabs: "O people! Your Lord is One, and your father is one. You are all Adam's children, and Adam has been created from dust. The most honourable among you in the sight of Allah is the most pious. No Arab has an advantage over non-Arabs except on account of their piety" (Al-Tirmidhi, 1300 A. H.) [5], thus, the Prophet (PBUH) affirmed the equality of humans: "there is no advantage for a black man over a red one and no advantage for a red over a black except in devotion to Allah." (Ahmad, 1313 A. H.) [6] Hereby, Islam has decreed an eternal law among people that all of them are equal: Arabs and non-Arabs, black and white, they are only distinguished by their devotion to Allah. Accordingly, Islam has made the real brotherhood to help each other rather than to compete, exploit, assimilate and colonize other people and individuals (Wang, 2009) [7].

\subsection{Peaceful Coexistence}

If one's question is how the relationships of Muslims with non-Muslims, then the definite answer for this frequently raised question is their relationships are based on the brotherhood of humanity which indicated the Hadith: "I witness that all worshipers are brothers." (Ahmad, Al-Musnad, No. 18868; Abu Dawud, AlSunan, No. 1292). And which as Allah the Almighty emphasized on in the Holy Quran: "Allah does not forbid you from those who do not fight you because of religion and do not expel you from your homes - from being righteous toward them and acting justly toward them. Indeed, Allah loves those who act justly." (AlMumtahinah: 8)

Accordingly, the Muslims coexist with non-Muslims peacefully and cooperate with them in righteousness and goodness of the society. Because, as human being we share the common values, such as: justice, freedom, equality, faithfulness, virtue, integrity, conscience, probity and so on so forth. These values shared by all religions and civilizations for establishing a peaceful, solidary, stable, reciprocal, and harmonious society in any nations. Furthermore, Islam always calls either Muslims or non-Muslim to help the weak and the 
oppressed in the land, support the affairs pertaining to justice and freedom, resist oppression and aggression, and fight corruptions and evils.

Certainly, the best example which manifests the systemized PR in the Islamic Society under the leadership of the Prophet is the Medina Convention or Chapter when he (PBUH) migrated from Makah to Medina. The Medina Convention had been concluded with the Jews and disbelievers of Medina and included forty seven provisions (Ibn Hisham) [8] dealing with the internal relations as well as external relations. We may illustrate some of its relevant provisions for the study as follows (Haykal, 1980) [9]:

"In the name of Allah, the Most Gracious, the Most Merciful. This is a writing of the Prophet Muhammad (PBUH) between the Muslims of (Makkah) Quraysh and Yathrib (Medina) and those who follow them and are attached to them who struggled along with them:

a. They are a single Community (Ummah) distinct from (other) people.

b. The emigrants of Quraysh, according to their former condition, pay jointly the blood-money between them, and they (as a group) ransom their captive(s), (doing so) with uprightness and justice between the believers.

c. The believers do not forsake a debtor among them, but give him (help), according to what is fair for ransom or blood-wit.

d. The believers who fear Allah are against whoever of them who acts wrongfully or seeks (plans) an act that is unjust or treacherous or hostile or corrupt among the believers; their hands are all against him, even if he is the son of one of them.

e. A believer does not kill a believer because of an unbeliever, and does not help an unbeliever against a believer.

f. Whoever of the Jews follows us has the (same) help and support (as Muslims) as long as they are not wronged and he does not help (others) against them.

g. The security (Dhimmah) of Allah is one; the granting of 'neighbourly protection' (Yujir) by the lowliest of them (the believers) is binding on them; the believers are protectors of one another to the exclusion of (other) people.

h. In every expedition made with us the parties take turns with one another.

i. The peace (Silm) of the believers is one; no believer makes peace apart from another believer, where there is fighting in the way of Allah, except in so far as equity and justice between them (is maintained).

j. The believers exact vengeance for one another where a man gives his blood in the way of Allah. The Allahfearing believers are under the best and the most correct guidance.

k. It is not for a believer who has agreed to what is in this document (Sahifah) and believed in Allah and the Last Day to help a wrong-doer or give him shelter. If anyone helps him or gives him shelter, upon this man is the curse of Allah and His wrath on the Day of Resurrection, and from him nothing will be accepted to make up for it or take its place.

1. Wherever there is anything about which you differ, it is to be referred to Allah and to Muhammad (PBUH).

$\mathrm{m}$. The Jews share the expenses with the others as long as they continue (or fight) during war.

n. The Jews of Banu 'Awf are a separate community from the believers. To the Jews their religion and to the Muslims their Religion. (This applies both to their clients and to themselves,) with the exception of anyone who has done wrong or acted treacherously; he brings evil only on himself and on his household.

o. No one of them (members to the Ummah) may go out (to war) without permission of Muhammad (PBUH), but he is not restrained from taking vengeance for wounds. Whoever acts rashly, it is only himself and his household, except where a man has been wronged. Allah is the Truest One on this (document).

p. It is for the Jews to bear their expenses and for the Muslims to bear their expenses. Between them (that is, to one another) there is help against whoever fights against the people of this documents. Between them is sincere friendship, and honourable dealing, not treachery. A man is not guilty of treachery through (the act of) his confederate. There is help for the person wronged.

q. The 'protected neighbour' is as the man himself as long as he does not harm and does not act treacherously.

r. No 'neighbourly protection' is given to the Quraysh and those who help them.

s. Between them is help against whoever suddenly attacks Yathrib.

t. Whenever they are summoned to conclude and accept a treaty, they conclude and accept it; when they have kept (their word), it is a duty of the believers (to protect them), and all men have to support each other except fighting for Religion.

u. A person acquiring (guilt) acquires it only against himself. Allah is the Most Upright and Truest Fulfiller of what is in this document. This writing does not intervene to protect a wrong-doer or traitor. He who goes out is safe, and he who sits still is safe in Madinah, except whoever does wrong and acts treacherously. Allah is 'protecting neighbour' of him whom acts honourably and fears Allah, and Muhammad (PBUH) is the Messenger of Allah.

It is obvious that, as we have seen, the Madinah Convention, to which all the communities adhered, the Prophet (PBUH) considered the Muslims, whether exiles from Makkah (Muhajirun) or helpers from Madinah (Ansar), as one community (Ummah), while addressing each one of the Jewish communities as a separate entity. 
Those who allied themselves with the Muslims would have their support and be on an equal footing. The parties of the Convention would conduct war or peace collectively. No party would unilaterally conclude peace with a belligerent adversary or wage war against a third party by itself. No one among the non-believers was to grant protection to a Quraysh disbeliever or to his property. The Jews would share the expenses with the faithful. As long as they were fighting, the Jews of Banu 'Awf were an Ummah with the faithfulness, and the Jews had their own faith just as the Muslims had theirs. The parties of the convention would support each other against any other party that would attack Medina.

Although the communities of the Jews and disbelievers could not be considered as an independent state or being an independent authority, the Convention can be included in the type of making friendly relationship between two communities, i.e. the Muslim Community and non-Muslim Community, which had special identity and particular rulings in terms of subsistence, cooperation, supporting one another, and keeping peaceful relations towards each other, etc. (Al-Nawawi, 1974) [10]; thereupon, the Convention included that: "They are a single Community (Ummah) distinct from (other) people... To the Jews be their religion and to the Muslims be their religion..." (Ibn Hisham) [8]. Besides, it also included the rulings and principles of the rights of the international relations that must be respected, such as "The security (Dhimmah) of Allah is one; ... the believers are protectors of one another to the exclusion of (other) people.

\section{The OBJeCtives of ISLAMic Public Relations}

It is clear that in such social environment satisfied with recognizing the human's dignity and respecting each other, the society, then, could have the PR an instrument that may govern the behaviours of individuals and collectives, governors and the governed and also as a media aiming at connecting the state with the individuals and collectives by diverse means and approaches. Thereby, we might appreciate that the PR means to develop the reciprocal understanding and goodwill between the internal as well as external associations, institutions, organizations and among the public themselves in order to achieve three main objectives (Abu Sunna, 1986) [11], namely: propagation, persuasion, and participation. However, let us see how these objectives had been achieved by the Prophet (PBUH) and his companions in the early Islamic Society:

\subsection{Propagation}

Propagation is considered as the first and the most important objective for Islamic State to achieve. Masjid as the administration section was adopted by the Prophet (PBUH) and his companions for promoting and propagating Islam to all human beings. Moreover, he himself (PBUH) started with the closest one as the target of delivering the Message of Allah the Almighty, then followed by the neighbours and others in different and suitable occasions through the personal attachment, reciting and explaining the Quranic Verses, informing them with rewards of Allah the Exalted for believers and his punishment on the disbelievers. When the first Islamic State had been established in Medina, Muslims were shifted from the first objective to second another, which is to practicing Islam and all requirements under the leadership of the Prophet (PBUH), such as Salah (prayer), Zakah (compulsory welfare contribution of wealth), Siyam (fasting) and other social regulations and civil laws; to make this clear in our mind, we may illustrate the following Verse: "Righteousness is not that you turn your faces toward the east or the west, but [true] righteousness is [in] one who believes in Allah, the Last Day, the angels, the Book, and the prophets and gives wealth, in spite of love for it, to relatives, orphans, the needy, the traveller, those who ask [for help], and for freeing slaves; [and who] establishes prayer and gives Zakah; [those who] fulfill their promise when they promise; and [those who] are patient in poverty and hardship and during battle. Those are the ones who have been true, and it is those who are the righteous.” (Al-Baqarah: 177)

\subsection{Persuasion}

Persuasion, which is manifested through the Prophet (PBUH) by applying the eloquent conversation, reasonable dialogue and powerful influence of the Holy Quran to communicate with people for convincing them that Islam is the Truth from Allah the Exalted as a Mercy to human beings. As a matter of fact, the methodology of the Prophet (PBUH) for propagating Islam is the revelation of Allah: "Invite to the way of your Lord with wisdom and good instruction, and argue with them in a way that is best. Indeed, your Lord is most knowing of who has strayed from His way, and He is most knowing of who is [rightly] guided.” (An-Nahl: 125)

The IPR is considered as a social philosophy that every one who works at the Islamic organization (Zain, 2008). As long as the PR in its essence depends on the firmly behavioural principles, individuals or collectives are required to be conscientious, sincere, fair, faithful, honest, loyal, responsible and trustworthy in the daily dealings with others by aiming at obtaining their confidence and achieving the mutual understanding among themselves. Then, it is not different from ethics and moralities which Islam preaches and what had been practiced by the Prophet (PBUH) and his companions. However, in order for us to acquire the features and characteristics of IPR, we must display the ethics and moralities emphasized by Islam and by which the Prophet (PBUH) has been sent to all mankind. He (PBUH) said: "I have been sent to perfect the noble manners (ethics 
and moralities)" (Ahmad, Al-Musnad, No. 8729; Al-Bukhari, Al-Sahih, No. 273; Al-Baihaqi, Al-Sunan alKubura, No. 19143).

\subsubsection{Truthfulness}

It is well known that truthfulness as an essentially moral character which every human being is required to possess in order to render people consistently confide in what we are saying and what we are doing. As a consequence, it will bring us into success in the PR. The best example for us to imitate is the Prophet (PBUH) who was addressed by people as 'Al-Sadiq al-Amin' (the trustworthy and the truthful). Allah the Exalted commends HIS beloved Prophet (PBUH) in the Holy Quran: "And indeed, you are of a great moral character." (Al-Qalam: 4). And that is why Allah requires us to follow him (PBUH): "There has certainly been for you in the Messenger of Allah an excellent pattern for anyone whose hope is in Allah and the Last Day and [who] remembers Allah often." (Al-Ahzab: 21) Besides, Narrated "Abdullah bin Mas"ud: "the Messenger of Allah (PBUH) said: Truthfulness (Sidq) leads to righteousness (Birr), and righteousness leads to Paradise. And a man keeps on telling the truth until he becomes and is written as a truthful person (Siddiq). And Falsehood/lying (Kidhb) leads to Al-Fajur (wickedness, evil-doing), and Al-Fajur (wickedness) leads to the Fire, and a man may keep on telling lies till he is written before Allah, a liar (Kadhab)." (Ahmad, Al-Musnad, No. 3509 and 3631; Al-Bukhari, Al-Sahih, No.5658 and 6094; Muslim, Al-Sahih, No. 2607 and 4725).

It is clear after contemplating the Hadith that whosoever is truthful, he/she will be lead to do these vast good deeds and then eventually they will be written as a "Siddiq" who not only tell the truth, always speak the truth, and stand by it and live by it until it becomes his/her nature. On the other hand, the Prophet (PBUH) said that the man who lies will be lead to corruption and wickedness and then becomes as his nature and being written as a "Kadhab" who is always lying until it becomes his second nature and whose behaviours and actions are based on evil-doing and it is part of their character. One who is always lying until it's just second nature for lies to come out of his mouth. On the contrary, it was narrated by Abu Hurairah that the Prophet (PBUH) said: "Signs of hypocrite are three: as he speaks he lies; on making a promise he breaks it; and when charged with a trust he deceives." Furthermore, Al-Bukhari and Muslim reported the Hadith of 'Abdullah bin 'Umar with this addition: "and when he quarrels, he abuses." (Ahmad, Al-Musnad, No. 2/375; Al-Bukhari, Al-Sahih, No. 33, 2682, 2749 and 6095; Muslim, Al-Sahih, No. 59).

The same requirement applies to any organization too; otherwise it will get bogged down in reputation risk if we regard that the PR is about reputation-the result of what we say and what others say about us. In this sense, it is important for us to look after reputation with the aim of earning trust, understanding and support, and influencing views, opinions and behaviours between us and various publics - whether they are employees, customers, investors, consumers, local community - or all of those stakeholder groups. In fact, in our contemporary world, 'the excellent or good example' has been frequently utilized by medias and organizations as an third party to substitute many other efforts for changing views, promoting thoughts, advertising products, and so on so forth.

The straightforwardness in connection with transparency is a supplementary character of truthfulness in the relations with publics and is another important feature of successful PR in Islam, especially in response to the public opinion. The Prophet (PUBH) never left a social problem which concerned public without solving in his life, instead of, he listen to opinions raised from people and solve their problems in the light of Revelation. Following the Prophet (PBUH), the companions' administration is open to public for supervision in order to improve their performances and services for the public. Under such harmonious environment, the PR as management function that will identify, establish and maintain mutually beneficial relationships between an organization and the various publics on whom its success or failure depends (Cutlip, Center\& Broom, 2006) [12].

\subsubsection{Greeting with Salam, Smiling and Shaking one another's Hands}

Al-Bara' bin 'Azib (May Allah be pleased with them) reported: The Messenger of Allah (PBUH) commanded us to do seven things: to visit the sick, to follow the funeral (of a dead believer), to invoke the Mercy of Allah upon one who sneezes (i.e., by saying to him: Yarhamuk Allah), to support the weak, to help the oppressed, to promote the greeting of As-Salamu "Alaikum, and to help those who swear to do something to keep their oaths." (Ahmad, Al-Musnad, No. 18268; Al-Bukhari, Al-Sahih, No. 2278 and 2445; Muslim, AlSahih, No. 2068 and 3855). This Hadith indicates that Muslims towards one another have obligations which are considered as distinctive aspect of the Muslim's social conduct. Thus, by fulfilling these social responsibilities, it will create among them mutual love, a sense of cohesion and feelings of respect for one another, especially greeting of Salam has effects in spreading brotherly love and is a means of uniting. Regarding this matter and for further benefits, let us see the following teachings of the Holy Quran and the Noble Hadith:

\section{A. The Holy Quran:}


i. "And when you are greeted with a greeting, greet [in return] with one better than it or [at least] return it [in a like manner]. Indeed, Allah is ever, over all things, an Accountant." (An-Nisa: 86).

ii. Furthermore, another social etiquette that linked with greetings as a Quranic rule that: "O you who have believed, do not enter houses other than your own houses until you ascertain welcome and greet (by Salam) their inhabitants. That is best for you; perhaps you will be reminded." (An-Nur: 27)

\section{B. The Noble Hadith:}

i. 'Abdullah bin 'Amr (may Allah be pleased with them) said: "a man asked the Prophet (PBUH): Which aspect of Islam is best?' He said that feeding people and greeting (by Salam) those you know and those you do not know." (Ahmad, Al-Musnad, No. 6403 and 6545; Al-Bukhari, Al-Sahih, No. 1036 and 1050 and 2445; Muslim, Al-Sahih, No. 42 and 59).

ii. It is narrated by Abi Hurair (may Allah be pleased with him) that the Messenger of Allah (PBUH) said: "you will not enter Paradise until you believe, and you will not believe until you love one another. Shall I not tell you about something which, if you do it, you will love one another? Spread Salam (the greeting of peace) among you." (Ahmad, Al-Musnad, No. 10211 and 27314; Al-Bukhari, Al-Sahih, No. 975 and 980 and 2445; Muslim, Al-Sahih, No. 56 and 84).

iii. Abu Ayub al-Ansari (may Allah be pleased with him) reported that the Prophet (PBUH) said: "it is not permissible for a man to forsake his brother for more than three (days/nights), each turning away if they meet. The better of the two is the one who is the first to greet the other with Salam" (Ahmad, Al-Musnad, No. 22909 and 23016; Al-Bukhari, Al-Sahih, No. 401 and 406 and 2445; Muslim, Al-Sahih, No. 2563 and 4650).

Simultaneously, it is required by the IPR that gives our simile for people whomever we meet. Simply because the simile is a powerful instrument that will keep our friendly relationship with each other and which is encouraged by the Prophet (PBUH) as a given charity. It was reported by Abu Dharr (May Allah be pleased with him) that Allah's Messenger said: "Your smiling in the face of your brother is charity; enjoining the good $\&$ forbidding the evil is charity; your guiding a man that has lost his way is charity; and your removing of stones, thorns, and bones from people's paths is charity for you." (Al-Timidhi, Jami' al-Tirmidhi, No. 1876 and 1956; Al-Bukhari, Al-Sahih, No. 886 and 891; Al-Bahaqi, Al-Sunan, No. 18601). Furthermore, when we met and greeted each other with Salam, we might also shake one another's hand and which is also regarded as very important way of dealing with the PR in accordance with the teachings of the Prophet (PBUH) as Al-Bara bin "Azib (May Allah be pleased with them) reported Allah's Messenger (PBUH) said: "whoever two Muslims meet and shake hands, their (minor) sins are forgiven before they part with each other." (Ahmad, al-Musnad, No. 18121 and 18221; Al-Timidhi, Jami' al-Tirmidhi, No. 2671 and 2727; Al-Bahaqi, Al-Sunan, No. 12576).

\subsection{Participation}

Participation, which is regarded as another crucial approach for the Muslims to cooperate as well as are encouraged to contribute to the society. There is a principle which Allah the Exalted mentions in the Quran: "And whose affair is [determined by] consultation among themselves" (Al-Shura: 38). And another Verse instructs that: "And consult them in the matter." (Al 'Imran: 159) Accordingly, the Prophet (PBUH) used to consult his companions in the crucial social affairs, inter alai, the affairs pertaining to the war, the economics and administration. Thus, he (PBUH) had formed a committee consisted of fourteen members of the companions to discuss the affairs and matters related to the Islamic Society. Subsequently, the righteous companions had also followed this way of Shura in order to achieve the satisfying consequences of disposing the social affairs (Abu Sunna, 1981) [13]. Furthermore, Allah the Exalted commands us to co-operate each other in our social life: "And cooperate in righteousness and piety, but do not cooperate in sin and aggression." (AlMaidah: 2). Truly, if we assist and protect each other in the case of needs, then it will definitely reflect our brotherhood and solidarity that as Allah the Exalted requires us to follow: "The believers are but brothers, so make settlement between your brothers. And fear Allah that you may receive mercy." (Al-Hujurat: 10) Apart from this necessary requirement, another basic but essential principle which we should abide by in order to enhance our brotherhood is: "And hold firmly to the rope of Allah all together and do not become divided. And remember the favour of Allah upon you - when you were enemies and He brought your hearts together and you became, by His favour, brothers. And you were on the edge of a pit of the Fire, and He saved you from it. Thus does Allah make clear to you His verses that you may be guided." (Al 'Imran: 103) The Prophet (PBUH) had encouraged Muslims to participate with others in social life: "A believer who mixes with the people and endures the pain they inflict is more virtuous than one who does not mix with the people and bear that pain." (Ahmad, Musnad, No. 4875 and 5002; Al-Bukhari, Al-Sahih, No. 383 and 388; Al-Baihaqi, Al-Sunan al-Kubura, No. 18573).

It is obviously understood that the above-mentioned objectives once achieved within the PR, it demonstrates the power and solidarity of Muslims in the society, particularly the principle of Shura which will explore and show as well as to enhance and support the collective thoughts, mutual understanding and public 
opinion. Because this principle endows the individual's ability to face the social problems or the social affairs which shall be took into his/her consideration. Besides, it will make him/her to closely tie himself/herself with an association, institution or organization which he/she works in. Furthermore, another benefit of the principle together with the participation of the publics is that will provide opportunity for the institution to present its views, opinions, visions, policies, plans and programs for the public. In return, of course, the feedback of publics will improve the performance of the institution, because the public opinion in Islam indicates the trends of Muslim publics towards any affair concerns them in a particular period and society after consultancy, dialogue and discussion that are governed by the Holy Quran and the Sunnah of the Prophet (PBUH) (Khadr, 1987) [14]. Therefore, the intention or purpose by doing so is to convince the public and shift their attitudes and trends towards what the institution has presented. The satisfied achievements are the fruits of the PR which being treated by the beautiful manner and good words that as the Quran indicates: "Have you not considered how Allah presents an example, [making] a good word like a good tree, whose root is firmly fixed and its branches [high] in the sky? It produces its fruit all the time, by permission of its Lord. And Allah presents examples for the people that perhaps they will be reminded." (Ibrahim: 24-25)

Obviously, the repulsive approaches and the bad words will adversely affect the PR which as the Quranic Verse follows the above-stated that: "And the example of a bad word is like a bad tree, uprooted from the surface of the earth, not having any stability. Allah keeps firm those who believe, with the firm word, in worldly life and in the Hereafter. And Allah sends astray the wrongdoers. And Allah does what He wills." (Ibrahim: 26-26)

Moreover, inside consultation, lenience is a great gift from Allah. Thus, those who have not lenience are deprived from this bounty. As a PR consultant, should have much sympathy for publics, develop talents, recognize friends from enemies, select the best attitude, create kindness and love, and get a practical lesson for others. Therefore, we may pardon others for the injustice they treated to us, and for the sin they committed with respect to Allah, seek forgiveness from Allah for them and keep them in the scene by consulting with them in the political, social and economic affairs. For example, in administration scope, once lenience is needed, like the following verse: “... pardon them ..." while in another occasion intensity and severity is necessary. Allah the Exalted says in the Holy Quran: "So by mercy from Allah, [O Muhammad], you were lenient with them. And if you had been rude [in speech] and harsh in heart, they would have disbanded from about you. So pardon them and ask forgiveness for them and consult them in the matter. And when you have decided, then rely upon Allah. Indeed, Allah loves those who rely [upon Him].” (Al 'Imran: 159)

Again, Allah the Exalted says in the Holy Quran: "And do not turn your cheek [in contempt] toward people and do not walk through the earth exultantly. Indeed, Allah does not like everyone self-deluded and boastful. And be moderate in your pace and lower your voice; indeed, the most disagreeable of sounds is the voice of donkeys." (Luqman: 18-19)

For the commentary on this Verse, it is better to refer back to the authentic Hadith that: The Prophet (PBUH) said, "He who has, in his heart, an ant's weight of arrogance will not enter paradise." Someone said: "A man likes to wear beautiful clothes and shoes?"' Messenger of Allah (PBUH) said, "Allah is Beautiful, He loves beauty. Arrogance means ridiculing and rejecting the Truth and despising people." (Ahmad, Musnad, No. 6350 and 6490; Al-Hakim, Al-Mustadrik, No. 68). Obviously, the Hadith is a signal of warning to us that a man who has even an iota of pride in his heart will be barred from entering paradise. If pride incites a man to deny the existence of Allah and His Revelation, he is sure to be thrown into Hell. He also faces Divine displeasure and the danger of infernal fire if mere consideration of riches, physical beauty, social and intellectual prominence and family status makes him proud and self-conceited and he looks down upon others, or persists in the denial of Truth. Therefore, we must not boast of our power and behave arrogantly towards our fellow-humans. Instead of adopting a proud attitude, we should be hummable enough to conduct with publics in general and in PR field in particular.

Last but not least, we should always remind each other what have done with others in this world. Remembering that one day we definitely will accounted in front of Allah, there we must account ourselves before we are accounted. Allah the Almighty says in the Holy Quran: "O you who have believed, fear Allah. And let every soul look to what it has put forth for tomorrow - and fear Allah. Indeed, Allah is acquainted with what you do. And be not like those who forgot Allah, so He made them forget themselves. Those are the defiantly disobedient." (Al-Hashr: 18-19)

\section{CONCLUSION}

The principles and objectives of Islamic Public Relations are undoubtedly rooted in the conjunctions of Holy Quran and had been well practiced by the beloved Prophet Muhammad (PBUH) and his companions in the early period of Islamic State. The implications of principles on all institutions render people - Muslims and nonMuslims - to love, support and corporate each other who will eventually live peacefully and prosperously in a harmonious society. Therefore, invoking the Islamic values and reflecting the Maslah (public benefit) imply PR 
institutions or organizations must not be solely oriented toward profit; rather they must seek to promote the social welfare and protect the needs of society as a whole (Dasuki, 2007) [15].

To conclude, the PR consultancy potential in the Muslim World is great since the principles and objectives of PR are enshrined in the Islamic Shari'ah sources. Thus, IPR should be the hub in the field of inviting all that is good, enjoining what is right and forbidding what is wrong. Given all of the above-mentioned, this hummable paper suggests the importance of IPR training programs in light with the Islamic values to educate PR professionals and practitioners in the Muslim countries. We do believe that these programs could not only promote better understanding between institutions, publics and stakeholders, but also would improve their mutual relationships and contribute to the society which they live in.

\section{REFERENCES}

[1] Muhi Mahmud Hasan, and Samir Hasan Mansir, Al-'Alaqat al-'Ammah wal-I'lam fi al-Duwal al-Nammiyah (Alexandria: al-Maktab al-Jami'i al-Hadith, 1985, p 15).

[2] Zain, Mansur 'Uthman Muhammad, Al-Manzur al-Islamiyyi lil-'Alaqat al-'Ammah: Majallah Dirasat D'awiyyah (Sudan: International University of Africa, 2008, No. 15, pp. 137-172).

[3] A. Al-Kandari, and T.K. Gaither, Arabs, the West and Public Relations: A Critical/Cultural Study of Arab Cultural Values. Public Relations Review, 37(3), 2011, 266-273.

[4] Ibn Shuja', Shayrawayh bin Shahradan bin Shayrawayh al-Daslami al-Hamdani. Al-Firdaws bi Uthur al-Khitab, (Beirut: Dar alKutub al-Ilmiyyah, 1986, vol. 4, p. 30).

[5] Al-Tirmidhi, Muhammad bin 'Isa bin Surah, Jami’ al-Tirmidhi (or Sunnan) (India: Tubia' fi Dahali, 1300 A H, vol. 5, p. 389).

[6] Ahmad, Ibn Hanbal. (1313 A. H). Al-Musnad. ed. Ahmad Shakir (Beirut: Daar Ma'arif. vol. 2, pp. 644, 951, 963-964, 1130).

[7] Yongbao Wang, Diplomacy: Theory \& Practice in Islam (Selangor, Malaysia: International Islamic University Malaysia, 2009, pp. 10-11).

[8] Ibn Hisham, Abu Muhammad 'Abdul-Malik bin Ayyub al-Hamiri (d. 213 or 217 A. H.), Al-Sirah al-Nabawiyyah. ND. 2nd ed. (Cairo: Sharikat Maktbah wa Matbah'ah Mustafa al-Babi al-Halabi wa Awladuh bi-Misr. vol. 2, pp. 147-150).

[9] Haykal, Muhammad Husayn.. Hayah Muhammad. 13th ed. (Cairo: Maktabah an-Nahdhah al-Misriyyah, 1980, pp. 225-227).

[10] Al-Nawawi, 'Abdul-Khaliq, Al-'Alaqat al-Duwaliyyah wa al-Nuzm al-Qada'iyyah fi al-Shari'ah al-Islamiyyah (Beirut: Dar al-Kitab al-'Arabi, 1974, p. 76).

[11] Abu Sunna,. (1986). Al-'Alaqat al- 'Ammah fi al-Dawlah al-Hadithah (Dubai: al-Matba'ah al-'Asriyyah, 1986, pp. 22).

[12] S.M. Cutlip, A.H. Center, and G.M. Broom, Effective Public Relations. 9th ed (Englewood Cliffs, NJ: Prentice-Hall, 2006, pp. 5-11).

[13] Abu Sunna, Ahmad Ibrahim. Al-Idarah fi al-Islam (Dubai: Al-Matba'ah al-'Asriyyah, 1981, p. 70).

[14] Khadr, Muhammah Hamd, Mutala'at fi al-I'lam (Makah: Maktabah al-Talib al-Jami'I, 1987, pp. 72-73).

[15] A.W. Dasuki, and N.I. Abdullah. (2007). Maqasid al-Shari'ah, Maslahah, and Corporate Social Responsibility, the American Jornal of Islamic Social Sciences, 24(1), 2007, 25-45. 